\title{
DETERMINATION OF THE MOST INFLUENTIAL FACTORS IN THE CONCENTRATION OF BACTERIA IN COASTAL WATERS
}

\author{
A. PALAZÓN ${ }^{1}$, L. ARAGONÉS ${ }^{2}$, I. LÓPEZ ${ }^{2}$, R. LÓPEZ-ÚBEDA ${ }^{3} \&$ J.M. SAVAL ${ }^{2}$ \\ ${ }^{1}$ Department of Civil Engineering, Catholic University of Murcia, Spain \\ ${ }^{2}$ Department of Civil Engineering, Alicante University, Spain \\ ${ }^{3}$ Department of Physiology, Veterinary Faculty, University of Murcia, Spain
}

\begin{abstract}
Control of water quality of coastal waters is essential to ensure the safety of bathers. Therefore, the current legislation establishes maximum concentration levels of faecal bacteria, in particular Escherichia coli and intestinal Enterococci. After several studies, it is known that there are environmental and physical factors such as the level of urbanization of the beach, sediment type, rainfall, salinity and water temperature, which influence the concentration of these bacteria. However, there are many other factors, such as the morphology of the beach, its orientation relative to waves and the proximity of spills, that can affect the survival of these bacteria and therefore directly influence the water quality in the coastal zone. In this article, 270 beaches between the provinces of Valencia and Granada (Spain) were analysed. It was observed that the local factors that further affect the concentration of faecal bacteria in coastal water are the presence of meadows of Posidonia oceanica, the orientation of the beach with respect to the direction of the most common incident waves and the agricultural discharges in the sea.
\end{abstract}

Keywords: Coastal discharges, E. coli, Enterococcus, Posidonia oceanica, water quality

\section{INTRODUCTION}

The Mediterranean coast is one of the largest touristic zones of Spain, especially the beach tourism. The good weather conditions, practically throughout the year, ensure that coasts are visited by many tourists, contributing significantly to the GDP of the area and therefore the national one [1]. The beaches, conceived as bathing areas or activities related to it, are the essential elements around which economy develops in this area. Thus, it is essential that they have an acceptable quality and that under no circumstances endanger the health of the bather [2]. One of the factors that indicate the quality of bathing waters is the concentrations of $E$. coli and Enterococci [3,4]. These bacteria reach the sea, directly (by outfalls by bathers themselves) or indirectly, to dilute its load, mitigating the potential contamination [5].

Directive 2006/7/EC of the European Parliament and of the Council of 15 February 2006 concerning the management of bathing water quality establishes the limits maximum of concentration for faecal bacteria to ensure the quality of bathing water. Although most of these bacteria are not harmful, some strains produce toxins that can be transmitted to humans causing various diseases $[6,7]$.

Recently, it has been studied that various factors can influence more in the concentration of these bacteria, particularly proving that solar radiation and sunshine hours are the factors that affect mainly due to their elimination in coastal waters. It has also been found that concentration in the gravel beaches is lower than in sand beaches, due to the type of wave break producing lower turbidity in the water [8].

Therefore, from the study of Aragonés et al. [8] the global factors affecting the concentration of faecal bacteria in a large study (Spanish coast) are studied. It is intended to determine local variables that most affect concentration. 


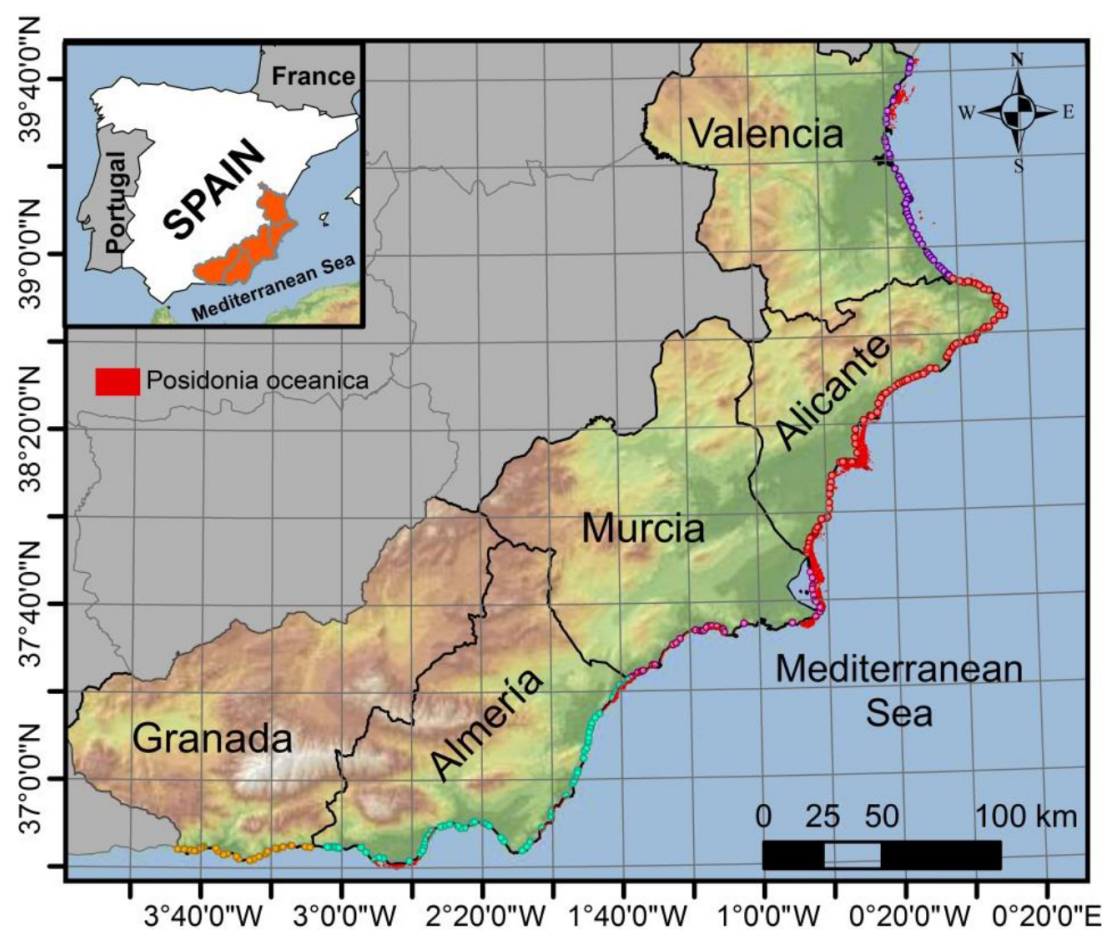

Figure 1: Location of the study area.

To do this, an area with similar characteristics (salinity, sunshine, water temperature, rainfall and UV) was selected. Thus, an analysis of the concentrations of E. coli and Enterococci at beaches located between the provinces of Valencia and Granada (Spain) was performed, depending on various factors such as the biocenosis of the area, morphology and orientation.

\section{STUDY AREA}

The study area comprises the 270 beaches on the Mediterranean coast in the provinces of Valencia ( 47 beaches), Alicante ( 94 beaches), Murcia ( 37 beaches), Almería ( 65 beaches) and Granada (27 beaches) (Fig. 1). There are important contrasts within the study area, such as large agricultural activities bordering the coast, large urbanized areas, coves and cliffs, extensive coastal dune ridges, lagoons, gravel and sand beaches, important areas of seagrass meadows, rivers and ravines mouths and rainfall variations from one place to another $[9,10]$.

\section{METHODOLOGY}

The process followed to obtain the results in this article is described subsequently. The study was conducted in three phases: data collection, organization and classification of data, and finally analysis.

Table 1 shows the studied factors and the source from which they have been obtained.

The concentration of Escherichia coli and Enterococci in each of the beaches was obtained from the public database published by Nayade [11] from surveys conducted from 2012 to 
Table 1: Summary of parameters analysed and data sources.

\begin{tabular}{lcl}
\hline Parameters & Sampling & Source \\
\hline Faecal bacteria & $2012-2015$ & $\begin{array}{l}\text { Sistema de Información Nacional de } \\
\text { Aguas de Baños, Nayade [11] }\end{array}$ \\
$\begin{array}{l}\text { Morphology, orientation and } \\
\text { environmental factors (Posidonia } \\
\begin{array}{l}\text { oceanica }, \text { types of coastal } \\
\text { discharges) }\end{array}\end{array}$ & 2006 & $\begin{array}{l}\text { Estudio ecocartográfico de las } \\
\text { provincias de Valencia y Alicante, }\end{array}$ \\
& and & $\begin{array}{l}\text { Ecolevante [9] } \\
\text { Estudio ecocartográfico de las } \\
\text { provincias de Granada, Almería y } \\
\text { Murcia, EcoMAG [10] }\end{array}$ \\
\hline
\end{tabular}

2105 (See http://nayade.msc.es/Splayas/home.html for more information about how the samples were collected, the periodicity of the sampling and quantification methods $E$. coli and Enterococci). These data were processed in accordance with the Directive 2006/7/EC and the related Royal Decree (RD 1341/2007), to obtain the values of E. coli and Enterococcus in each one of the beaches. The data used in this study correspond to the 95th percentile values in accordance with the Directive.

On the other hand, for each of the beaches the morphology, orientation, types of discharges near the beaches and the presence of Posidonia oceanica were determined. These data were obtained by using a GIS (Geographic Information System) and the studies [9] and [10].

To determine the type of discharge near each beach, the distance between each discharge point and the midpoint of the beach was determined (by measuring the distance in the direction of the main direction of waves in each area). Having done this, what was considered as littoral discharge on the beach is the one that was closest, provided the distance was less than $2 \mathrm{~km}$. If the distance of the discharge point was greater than $2 \mathrm{~km}$, it was considered that there was no discharge on the beach.

Table 2 shows the different categories in which each of the factors studied were grouped.

Finally, using SPSS 20.0 statistical package an analysis of variance (one-way ANOVA) was performed to study whether there were significant differences between the concentration of bacteria (E. coli and Enterococcus) and each of the considered factors. To do this, first it was examined whether the assumptions of normality and equality of variances, which are necessary for ANOVA, were satisfied, the assumption of equal variances between different subgroups being the most important. The assumption of normality was determined using the Kruskal-Wallis test and for the analysis of homogeneity of variance Levene's test was used. The ANOVA analysis was performed using the Tukey test when there was equality of variances. When there was no equality of variances, Games-Howell test and nonparametric tests defined by test and Welch Brown-Forsythe were used. Finally, a correlation between the studied factors was performed.

\section{RESULTS}

First statistical data for sampling of faecal bacteria E. coli and Enterococci of the five studied provinces are shown (Table 3). Note that the maximum values for E. coli are found in Valencia with 598.7 CFU/100 ml followed distantly by Granada and Almeria (418.0 and 264.7 CFU/100 ml, respectively). Something similar happens in the case of Enterococci, being the maximum values in Valencia and Alicante (483.0 and $192.7 \mathrm{CFU} / 100 \mathrm{ml}$, respectively). The 
Table 2: Grouping of studied variables.

\begin{tabular}{|c|c|c|c|}
\hline Variables & Number of groups & \multicolumn{2}{|c|}{ Groups } \\
\hline Morphology & 4 & \multicolumn{2}{|c|}{$\begin{array}{l}\text { Open beaches } \\
\text { Supported beaches } \\
\text { Bi-supported beaches } \\
\text { Enclosed beaches }\end{array}$} \\
\hline Orientation & 14 & $\begin{array}{l}\mathrm{N} \\
\mathrm{NNE} \\
\mathrm{NE} \\
\text { ENE } \\
\text { E } \\
\text { ESE } \\
\text { SE }\end{array}$ & $\begin{array}{l}\text { SSE } \\
\text { S } \\
\text { SSW } \\
\text { SW } \\
\text { WSW } \\
\text { W } \\
\text { WNW }\end{array}$ \\
\hline Discharges & 8 & $\begin{array}{l}\text { Ravir } \\
\text { River } \\
\text { Outfa } \\
\text { Subm } \\
\text { Agric } \\
\text { Diffu } \\
\text { Storn } \\
\text { (D) } \\
\text { WW' } \\
\text { Treat } \\
\text { No di }\end{array}$ & $\begin{array}{l}\text { fall (SO) } \\
\text { A) } \\
\text { trial, } \\
\text { d Urban } \\
\text { ewater } \\
\text { t) }\end{array}$ \\
\hline $\begin{array}{l}\text { Posidonia } \\
\text { oceanica }\end{array}$ & 2 & $\begin{array}{l}\text { Yes } \\
\text { No }\end{array}$ & \\
\hline
\end{tabular}

minimum values are achieved in Murcia, Almeria and Granada for both bacteria. As for the mean values of $E$. coli, there are significant differences between provinces, being similar in the provinces of Alicante and Granada (41.3 \pm 3.7 and 41.9 $\pm 15.5 \mathrm{CFU} / 100 \mathrm{ml}$, respectively). While for Enterococcus, only the province of Valencia is very different from other provinces (61.7 $\pm 10.7 \mathrm{CFU} / 100 \mathrm{ml})$.

According to the morphology, beaches can be distinguished in four types, as proposed by López et al. [12]. The results of the concentrations obtained according to morphology are reflected in Table 4 . As can be seen $54.8 \%$ of the beaches are open while only $9.3 \%$ are bi-supported. Regarding the ANOVA, there are no significant differences between any of the groups, with mean values around $44.8 \mathrm{CFU} / 100 \mathrm{ml}$ for E. coli and $30.9 \mathrm{CFU} / 100 \mathrm{ml}$ for Enterococci. The mean value of the Enterococci in bi-supported beaches is remarkable (41.6 $\pm 18.6 \mathrm{CFU} / 100 \mathrm{ml})$.

Regarding the orientation of the beaches, it was classified by dividing the compass rose (360) each $22.5^{\circ}$ in 16 groups. Each sector includes the previous and next $11.25^{\circ}$ after the above cardinal directions. The predominant orientations are E, ESE and SE. In Fig. 2 the corresponding bacterial concentrations to each direction are reflected. As seen the beaches oriented NE and adjacent orientations are those with highest concentration of bacteria. Apparently, also those oriented WNW have high values, but a detailed analysis shows that there is only one beach with this orientation, and may not be valid to confirm the trend. 
Table 3: Statistics of faecal bacteria by provinces. Different letters (a, b, c) in the same column indicate significant differences $(p<0.05)$.

\begin{tabular}{|c|c|c|c|c|c|c|c|}
\hline \multirow{2}{*}{ Province } & \multirow{2}{*}{$\mathrm{N}$} & \multicolumn{3}{|c|}{ E. coli $(\mathrm{CFU} / 100 \mathrm{ml})$} & \multicolumn{3}{|c|}{ Enterococci (CFU/100 ml) } \\
\hline & & Average & Min & Max & Average & Min & Max \\
\hline Valencia & 47 & $104.2 \pm 16.3^{\mathrm{a}}$ & 16.5 & 598.7 & $61.7 \pm 10.7^{\mathrm{a}}$ & 10.2 & 483.0 \\
\hline Alicante & 94 & $41.3 \pm 3.7^{\mathrm{b}}$ & 7.2 & 206.6 & $31.4 \pm 2.8^{\mathrm{b}}$ & 8.5 & 192.7 \\
\hline Murcia & 37 & $9.62 \pm 1.7^{\mathrm{c}}$ & 1.3 & 49.7 & $23.5 \pm 2.0^{\mathrm{b}}$ & 3.1 & 58.2 \\
\hline Almería & 65 & $28.1 \pm 5.5^{\mathrm{bc}}$ & 1.9 & 264.7 & $18.0 \pm 1.7^{\mathrm{b}}$ & 3.4 & 90.1 \\
\hline Granada & 27 & $41.9 \pm 15.5^{\mathrm{b}}$ & 1.0 & 418.0 & $21.4 \pm 5.6^{\mathrm{b}}$ & 2.1 & 147.0 \\
\hline
\end{tabular}

Table 4: Statistics of faecal bacteria by beach morphology. Different letters $(a, b, c)$ in the same column indicate significant differences $(p<0.05)$.

\begin{tabular}{|c|c|c|c|c|c|c|c|}
\hline \multirow{2}{*}{ Morphology } & \multirow{2}{*}{$\mathrm{N}$} & \multicolumn{3}{|c|}{ E. coli $(\mathrm{CFU} / 100 \mathrm{ml})$} & \multicolumn{3}{|c|}{ Enterococci (CFU/100 ml) } \\
\hline & & Average & Min & Max & Average & Min & Max \\
\hline Open & 148 & $47.9 \pm 5.6^{\mathrm{a}}$ & 1 & 441.7 & $30.4 \pm 2.5^{\mathrm{a}}$ & 2.1 & 177.8 \\
\hline Supported & 40 & $41.3 \pm 8.6^{\mathrm{a}}$ & 2.4 & 264.7 & $31.0 \pm 5.6^{\mathrm{a}}$ & 2.7 & 192.7 \\
\hline Bi-supported & 25 & $49.4 \pm 23.5^{\mathrm{a}}$ & 1.7 & 598.7 & $41.7 \pm 18.6^{\mathrm{a}}$ & 3.4 & 483.0 \\
\hline Enclosed & 57 & $37.1 \pm 5.0^{\mathrm{a}}$ & 1.3 & 206.6 & $27.7 \pm 2.4^{\mathrm{a}}$ & 2.7 & 83.8 \\
\hline
\end{tabular}

It is important to study pollution sources, since they are the main contributors of the faecal bacteria to the water. There is a greater density of discharges in the provinces of Valencia and Alicante, than in Murcia, Almería and Granada. In Valencia the agricultural discharges (irrigation canals, channels, etc.) dominate, while in Alicante the diffuse discharges and ravines. On the other hand, Almería and Granada have a greater number of outfalls and sewage treatment plants than other provinces (Table 5).

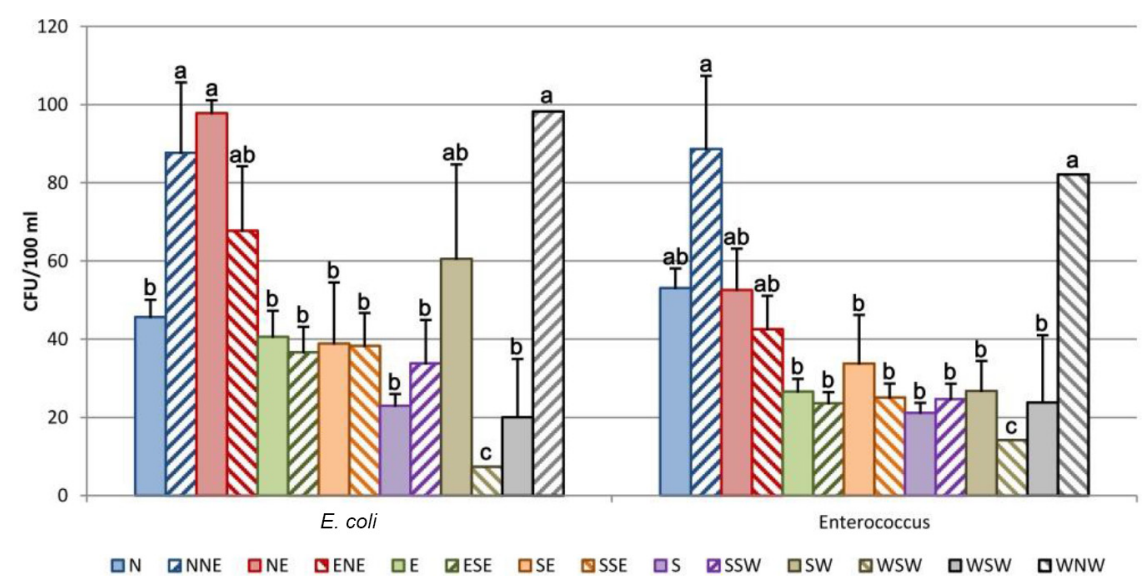

Figure 2: Statistics of faecal bacteria by beach orientation. Different letters $(a, b, c)$ indicate significant differences $(p<0.05)$. 
Table 5: Distribution of discharges by province.

\begin{tabular}{|c|c|c|c|c|c|c|c|c|}
\hline \multirow{2}{*}{ Province } & \multicolumn{7}{|c|}{ Coastal discharges } & \multirow{2}{*}{$\begin{array}{l}\text { No coastal } \\
\text { discharges }\end{array}$} \\
\hline & Rav. & $\mathrm{R}$ & $\mathrm{O}$ & SO & $\mathrm{A}$ & $\mathrm{D}$ & WWTP & \\
\hline Valencia & 0 & 7 & 0 & 3 & 24 & 13 & 0 & 0 \\
\hline Alicante & 32 & 14 & 2 & 4 & 5 & 37 & 0 & 0 \\
\hline Murcia & 14 & 0 & 0 & 0 & 1 & 21 & 0 & 1 \\
\hline Almería & 10 & 0 & 0 & 6 & 0 & 13 & 29 & 7 \\
\hline Granada & 4 & 3 & 0 & 7 & 2 & 4 & 7 & 0 \\
\hline
\end{tabular}

In Fig. 3 the mean values of bacteria concentration depending on the type of littoral discharge found in each beach are represented. As can be seen the bacteria concentration values are higher for the beaches that are closer to a river than a ravine $(62.1 \mathrm{CFU} / 100 \mathrm{ml}$ vs. 36.8 CFU/100 ml for E. coli and $37.3 \mathrm{CFU} / 100 \mathrm{ml}$ vs. $27.1 \mathrm{CFU} / 100 \mathrm{ml}$ for Enterococci).

On the other hand, there is a big difference between agricultural (95.1 and 62.6 CFU/100 $\mathrm{ml}$ for E. coli and Enterococci, respectively) and other discharges, stressing that the beaches located near the WWTP (32.6 and $19.6 \mathrm{CFU} / 100 \mathrm{ml}$ for E. coli and Enterococci, respectively), together with those that do not have any type of discharge $(9.6 \mathrm{CFU} / 100 \mathrm{ml}$ for $E$. coli and $12.0 \mathrm{CFU} / 100 \mathrm{ml}$ for Enterococci), present the lower contents of bacteria.

Among another studied variable is the existence of Posidonia oceanica, which have antibacterial activity against various bacteria, including E. coli [13]. The need for good transparency of water, coupled with its low tolerance to changes in salinity, eutrophication and most of the contaminants, makes that it is identified as a good bioindicator, showing areas of clean water, well oxygenated and free of pollution. The seabed in the province of Valencia is mostly of sedimentary nature. In the province of Alicante, there is a balance between the two bottom types with and without plant cover, as well as in Murcia and Almeria. While in Granada the Posidonia oceanica occupies small scattered areas (Fig. 1).

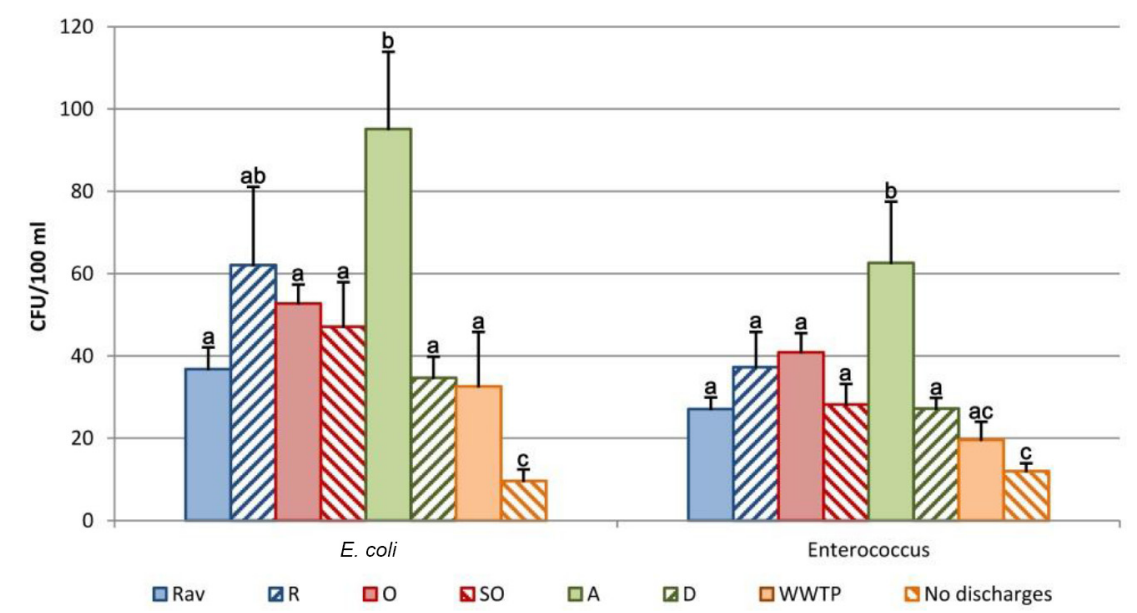

Figure 3: Statistics of faecal bacteria depending on the type of littoral discharge. Different letters $(\mathrm{a}, \mathrm{b}, \mathrm{c})$ indicate significant differences $(p<0.05)$. 


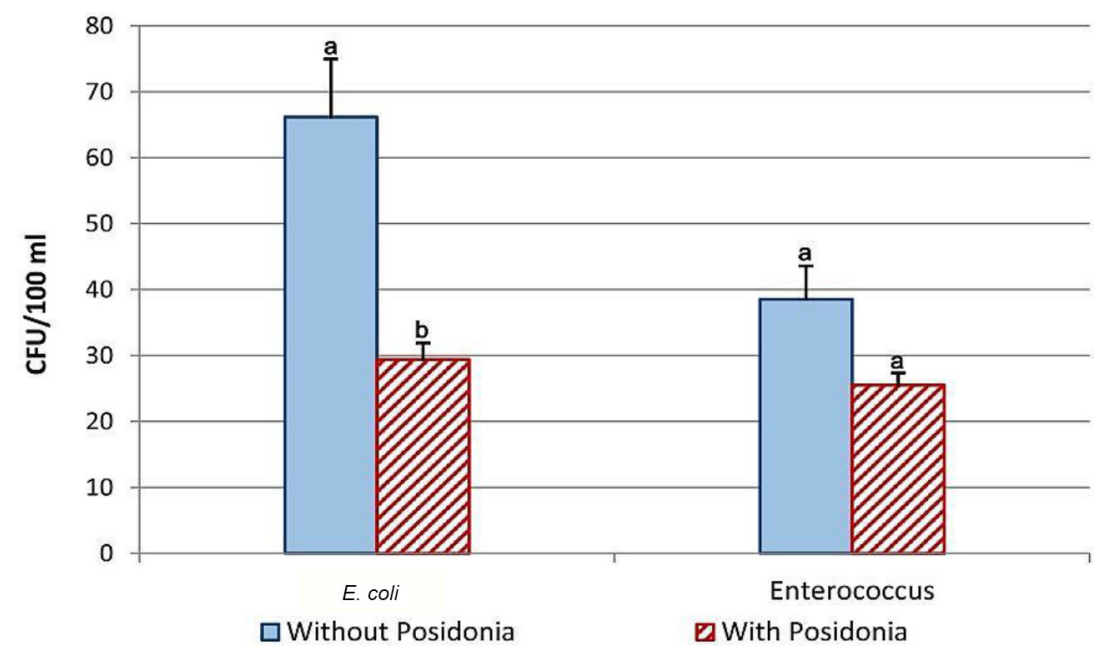

Figure 4: Statistics faecal bacteria based on the presence of Posidonia oceanica. Different letters $(\mathrm{a}, \mathrm{b}, \mathrm{c})$ indicate significant differences $(p<0.05)$.

Figure 4 shows the results obtained according to the presence or absence of Posidonia oceanica. Showing that mean values are higher in the beaches where there is no presence of Posidonia (66.2 \pm 8.8 vs. $29.4 \pm 2.5 \mathrm{CFU} / 100 \mathrm{ml}$ for E. coli and $38.5 \pm 5.1 \mathrm{vs.} 25.5 \pm 1.8 \mathrm{UFC} / 100$ $\mathrm{ml}$ for Enterococcus).

Finally, Table 6 shows the correlations between analysed faecal bacteria (E. coli and Enterococci) of all beaches and each of the studied parameters. The parameters that have larger correlation values with E. coli are the presence of Posidonia oceanica (-0.482) and discharges (-0.269). For Enterococci also the presence of Posidonia presents a good correlation $(-0.460)$, although for the other parameters the correlations are lower than 0.2. Finally, the correlation between the provinces and the E. coli and Enterococci is highlighted, more than 0.25 in both cases.

\section{DISCUSSION AND CONCLUSION}

A study of faecal bacteria was performed in the 270 beaches between the provinces of Valencia and Granada. These beaches have very similar environmental characteristics (UV, water temperature, rainfall, sunshine, etc.). Therefore, other local factors that can affect the concentration of these batteries were studied by analysing correlations and whether there are significant differences (ANOVA) between different defined subgroups. The studied factors are province, beach morphology, orientation, coastal discharges and presence of Posidonia oceanica.

Table 6: Correlations between faecal bacteria and the studied parameters.

\begin{tabular}{lccccc}
\hline Parameter & Province & Morphology & Orientation & Discharges & $\begin{array}{c}\text { Posidonia } \\
\text { oceanica }\end{array}$ \\
\hline E. coli & -0.285 & -0.056 & -0.141 & -0.269 & -0.482 \\
Enterococci & -0.315 & -0.002 & -0.183 & -0.163 & -0.460 \\
\hline
\end{tabular}


Regarding morphology, no big differences between different types of beaches are appreciated (Table 4), although bi-supported beaches present a slight increase in pollution in the waters compared with the mean value in the study area $(49.4 \pm 23.5$ vs. $44.8 \pm 4.1 \mathrm{CFU} / 100 \mathrm{ml}$ for $E$. coli and $41.7 \pm 18.6$ vs. $30.9 \mathrm{CFU} / 100 \mathrm{ml}$ for Enterococci). However, when analysing correlations (Table 6) no correlation was observed between bacteria and its morphology $(<0.05)$, so perhaps the increase in concentration in bi-supported beaches is not because of their morphology but other factors such as most of these beaches are mainly urban and sand [8].

Orientation, meanwhile, appears to have greater influence on the quality of bathing water (Fig. 2 and Table 6). The trend is clear, northeast facing beaches and adjacent containing a high concentration of faecal coliform in the water, which coincides with the predominant orientation of the waves in the study area [14]. From this, it could be deduced that the beaches whose shorelines are perpendicular to the front of waves take longer to remove bacteria, which may be due to two factors: (i) to the generated turbidity, which is inversely related to water quality [8] and (ii) the waves take coastal discharges closer to the coast.

When analysing the types of waste in a radius less than $2 \mathrm{~km}$ from the midpoint of the beach (Fig. 3) shows that the beaches that are near rivers contain $24.5 \%$ of E. coli and $11.5 \%$ of Enterococci more than those located close to a ravine. Notably it is not the only source of pollution to the sea so the rest of the discharges (wastewater or runoff) may influence these results. Regarding wastewater discharges, the most polluted beaches are located close to agricultural effluents, with more than twice the pollution than the average from other discharges (outfalls, submarine outfalls, diffuse discharges and WWTPs). This may be because land fertilizers can be a source of contaminants (in some cases, if they come from animal droppings), which can reach irrigation canals that flow directly into the sea without any prior purification.

The last studied variable was the Posidonia oceanica, a marine plant that lives only in the Mediterranean and forms large meadows on sandy bottoms near the coast. To develop, Posidonia meadows need good quality water, unpolluted, transparent and well oxygenated, so its presence is a representative of the quality of beaches in which it appears. Figure 4 shows the statistical results of this study; the beaches near these meadows had decreased concentration of $E$. coli in approximately 56 and $34 \%$ for Enterococci, which confirms its antibacterial function against $E$. coli bacteria [13].

The decrease in the concentration of bacteria in those beaches that have Posidonia oceanica could also be due to the effect of these on the waves. The friction of the plant leaves with water produces a reduction of the incident wave energy $[15,16]$, so a decrease in turbidity is achieved and therefore a greater action of ultraviolet radiation leading to greater purification of faecal bacteria [8]. The importance of the presence of Posidonia oceanica in reducing concentrations of E. coli and Enterococci is also demonstrated by the correlations (Table 6), with values higher than 0.45 for both bacteria.

Thus, from the foregoing it follows that when studying the concentration of bacteria in bathing water must be taken into account, in addition to climatic variables (sunshine, rainfall, temperature, etc.) and other local factors. Among the local factors, the possible coastal discharges and orientation of the beach with respect to the direction of the main waves in the area are highlighted. In addition, the different environmental factors that may affect the survival of faecal bacteria, as in our case the Posidonia oceanica, should be analysed.

\section{ACKNOWLEDGEMENTS}

The authors thank the Ministerio de Agricultura, Alimentación y Medio Ambiente and Jefatura Provincial de Costas de Alicante for the information they provided has enabled this study. 
This research has been partially funded by Universidad de Alicante through the project 'Estudio sobre el perfil de equilibrio y la profundidad de cierre en playas de arena' (YGRE15-02).

\section{REFERENCES}

[1] Yepes, V. \& Medina, J.R., Land use tourism models in Spanish Coastal Areas. A case study of the Valencia Region. Journal of Coastal Research, SI49, pp. 83-88, 2005.

[2] Sardá, R. \& Fluviá, M., Tourist development in the costa brava (Girona, Spain): A quantification of pressures on the coastal environment, Perspectives on Integrated Coastal Zone Management, eds. W. Salomons, R.K. Turner, L.D. Lacerda \& S. Ramachandran, Springer: Berlin \& Heidelberg, pp. 257-277, 1999.

[3] Yepes, V., La gestión de las playas basándose en normas de calidad y medio ambiente. Actas del II Congreso Internacional de Ingeniería Civil, Territorio y Medio Ambiente, Colegio de Ingenieros de Caminos, Canales y Puertos: Santiago de Compostela, Spain, pp. 835-846, 2004.

[4] Sardá, R., Ariza, E. \& Jimenez, J.A., Buscando el uso sostenible de las playas. En: Rodriguez-Perez, A, Roig, X., Pons, GX y JA Marín (eds.) La gestión integrada de playas y dunas: experiencias en Latinoamérica, Norte de Africa y Europa. Mon. Sociedad Historia Natural Balears, 18, pp. 13-21, 2012.

[5] Yamahara, K.M., Layton, B.A., Santoro, A.E. \& Boehm, A.B., Beach sands along the California coast are diffuse sources of fecal bacteria to coastal waters. Environmental Science \& Technology, 41(13), pp. 4515-4521, 2007. DOI: 10.1021/es062822n.

[6] Bosch, A., Lucena, F., Gironés, R. \& Jofre, J., Survey of viral pollution in Besós River (Barcelona). Water Pollution Control Federation, 58(1), pp. 87-91, 1986.

[7] Wyn-Jones, A. \& Sellwood, J., Enteric viruses in the aquatic environment. Journal of Applied Microbiology, 91(6), pp. 945-962, 2001. DOI: 10.1016/S0166-0934(00)00157-9.

[8] Aragonés, L., López, I., Palazón, A., López-Úbeda, R. \& García, C., Evaluation of the quality of coastal bathing waters in Spain through fecal bacteria Escherichia coli and Enterococcus. Science of The Total Environment, 566-567, pp. 288-297, 2016. DOI: 10.1016/j.scitotenv.2016.05.106.

[9] Ecolevante, Estudio ecocartográfico de las provincias de Valencia y Alicante, D.G.d. Costas (ed), Madris: Ministerio de Medio Ambiente, 2006.

[10] EcoMAG., Estudio ecocartográfico de las provincias de Granada, Almería y Murcia., D.G.d. Costas (ed), Madris: Ministerio de Medio Ambiente, 2009.

[11] Nayade., Sistema de Información Nacional de Aguas de Baño, 2015, available at http:// nayade.msc.es/Splayas/home.html (accessed 7 April 2016).

[12] López, I., Aragonés, L., Villacampa, Y., Compañ, P. \& Satorre, R., Morphological classification of microtidal sand and gravel beaches. Ocean Engineering, 109, pp. 309-319, 2015. DOI: 10.1016/j.oceaneng.2015.09.021.

[13] Hammami, S., Salem, A.B., Ashour, M.L., Cheriaa, J., Graziano, G. \& Mighri, Z., A novel methylated sesquiterpene from seagrass Posidonia oceanica (L.) Delile. Natural Product Research, 27(14), pp. 1265-1270, 2013. DOI: 10.1016/j.micres.2006.07.009.

[14] Estado, P.d., Puertos del Estado, 2012, available at http://www.puertos.es/en-us (accessed 15 December 2012).

[15] Méndez, F.J., Losada, I.J. \& Losada, M.A., Hydrodynamics induced by wind waves in a vegetation field. Journal of Geophysical Research: Oceans, 104(C8), pp. 18383-18396, 1999. DOI: $10.1029 / 1999 J C 900119$.

[16] Koftis, T., Prinos, P. \& Stratigaki, V., Wave damping over artificial Posidonia oceanica meadow: A large-scale experimental study. Coastal Engineering, 73, pp. 71-83, 2013. DOI: 10.1016/j.coastaleng.2012.10.007. 